ارزيابى مدل AquaCrop در شبيهسازى عملكرد و كارايى مصرف آب سيبزمينى تحت مقادير مختلف تنش آبى در دورههاى متفاوت رشد

\author{
محمد على انصارى'، اصلان اگدرنزاد 'و نيازعلى ابراهيمى ياك'

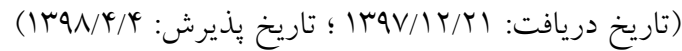

\begin{abstract}
جكيده

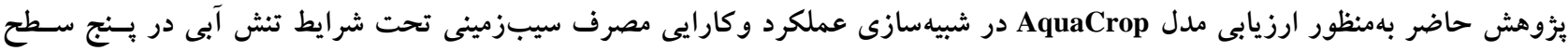

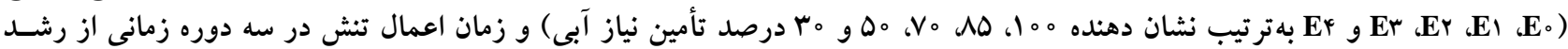

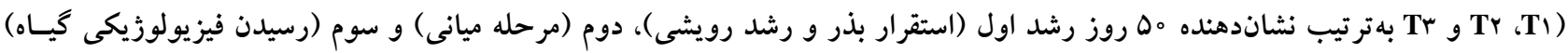

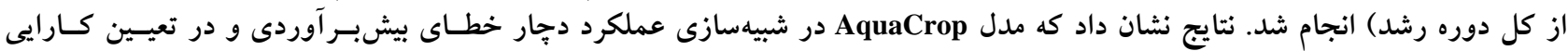

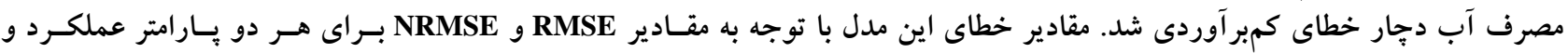

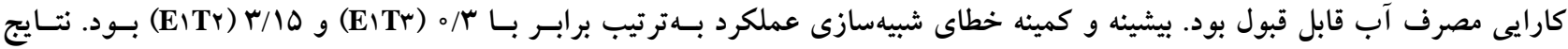

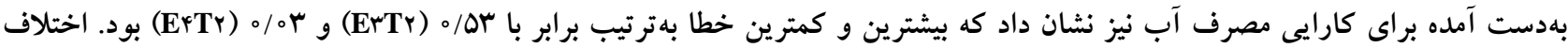

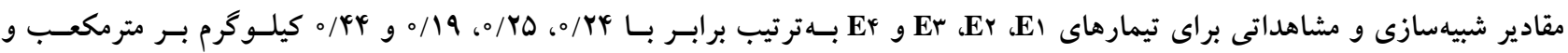

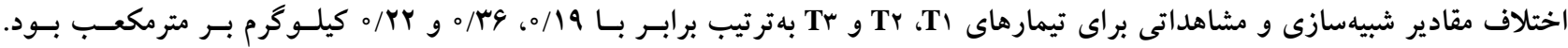

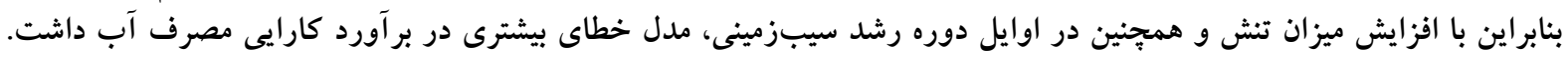

وازههاى كليدى: تنش آبى، عملكرد سيبزمينى، مدلسازى گياهى، مدل AquaCrop

ا. كروه علوم و مهندسى آب، واحد اهواز، دانشخاه آزاد اسلامى، اهواز، ايران

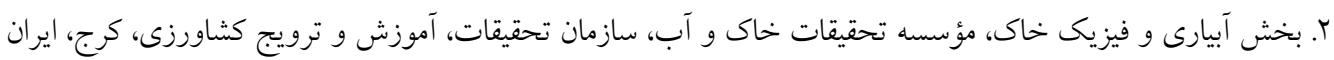

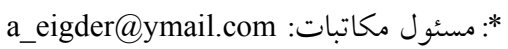


بودن و دقت قابل نسبت به ساير مدلهاى رشـــ گيـاهى برتـرى

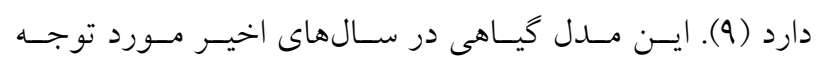
يززوهشكران مختلفى بوده است و بـهمنظور شبيهسـازى كياهـان

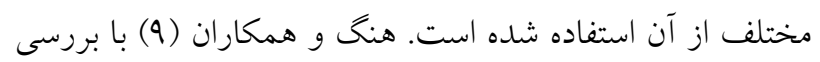

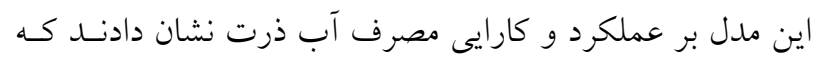

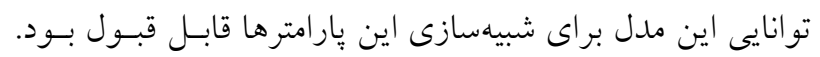

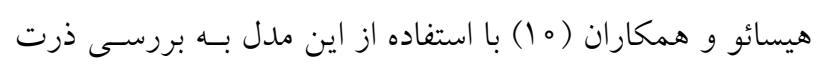

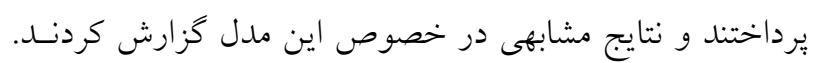

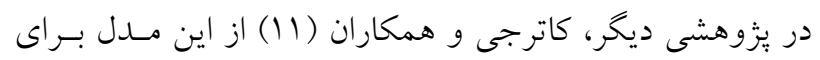

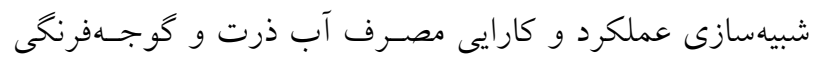

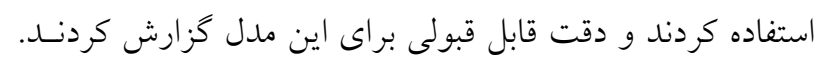

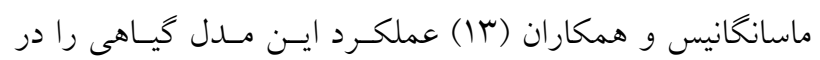

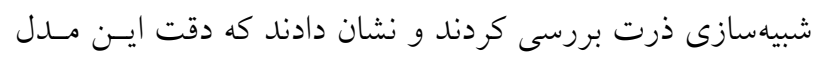

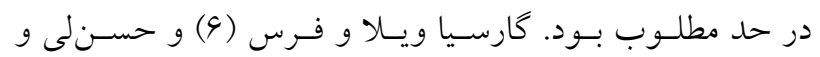

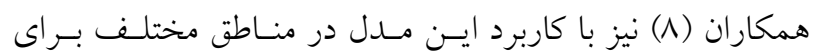
كَاهان مختلف نشان دادند كه دقت اين مدل قابل قبول بود.

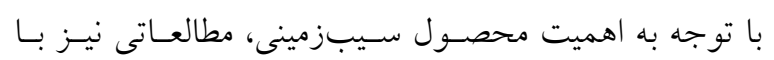

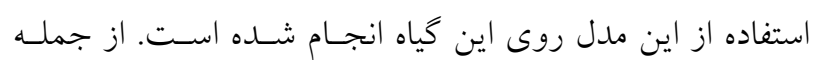

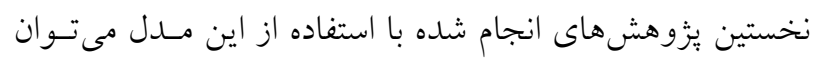

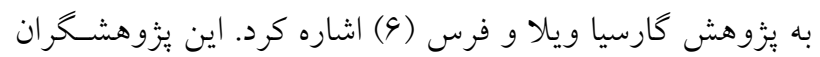

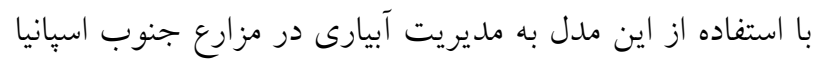

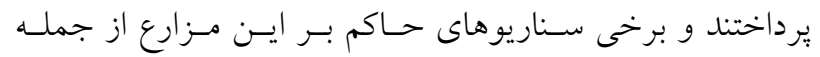
كاهش سطوح كشت و يا افزايش قيمـت محصـول را بــــا تغييـر سطوح آبيارى بررسى كردند. در مطالعه ديخرى كه توسط افشار

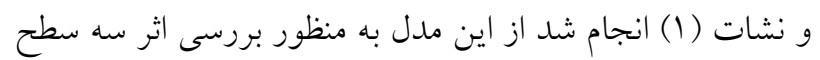

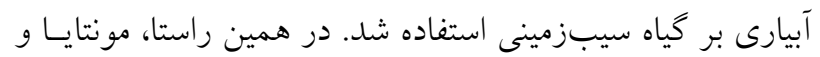

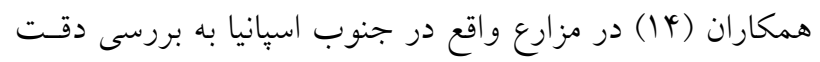

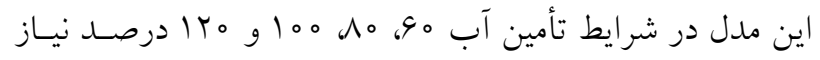
آبى سيبزمينى برداختند.

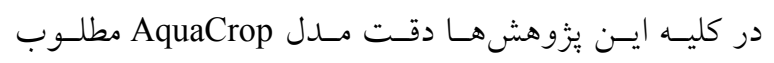

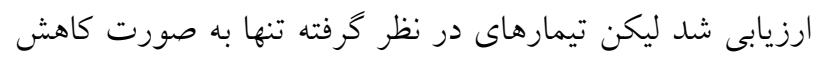
نياز آبى در كل دوره رشد در نظر كرفته شدند. درحالى كه مرور

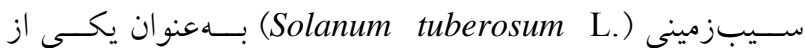

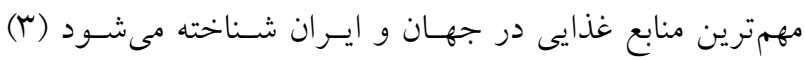
بهوطوى كه در رتبهبندى محصولات مهم غذايى در دنيـا در رده

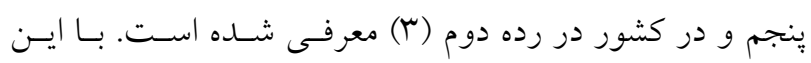

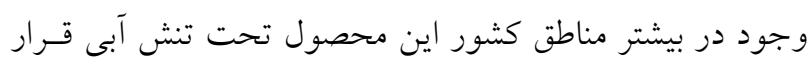

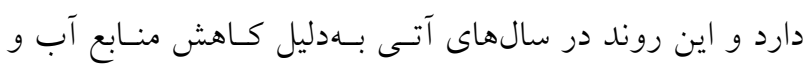

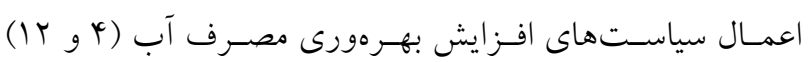

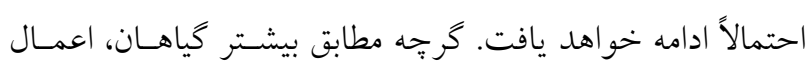

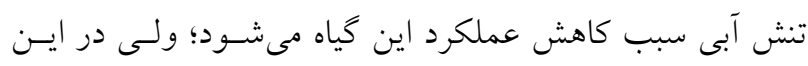

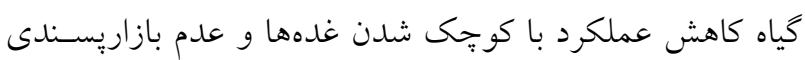

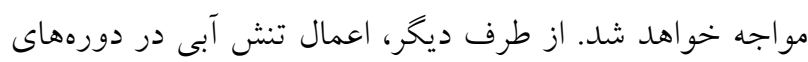

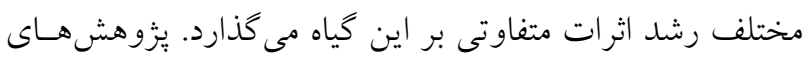
انجام شده در طى سالهاى كذشته نشـان داده اسـت كـه كليـهـ

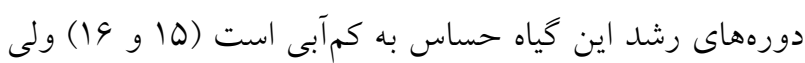

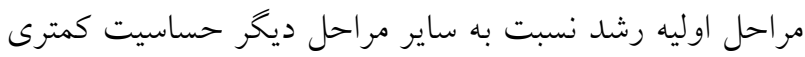

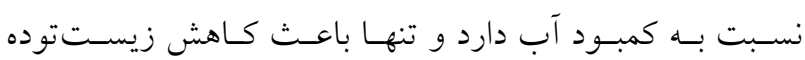

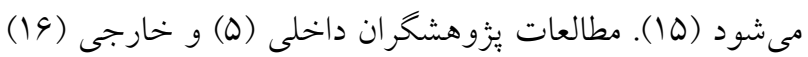

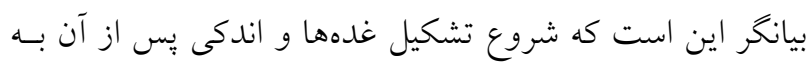

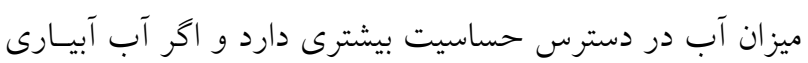

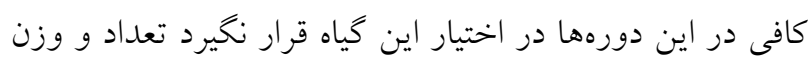
محصول بهشدت كاهش مى يابد.

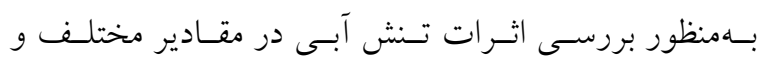

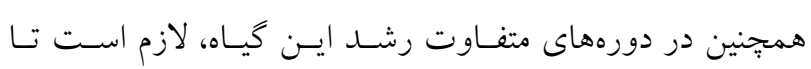
آزمايشهاى متعدد مزرعهاى در مناطق مختلف كشور انجام شود.

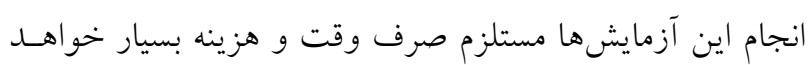

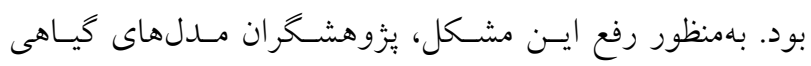

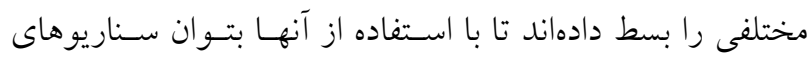

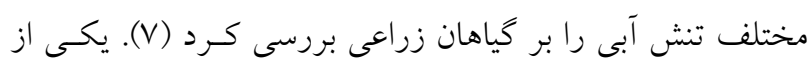

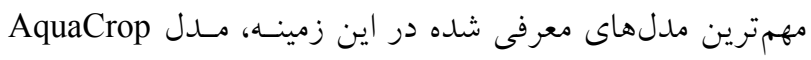

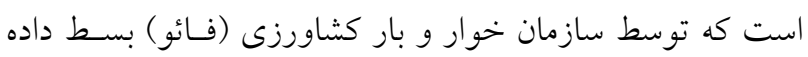

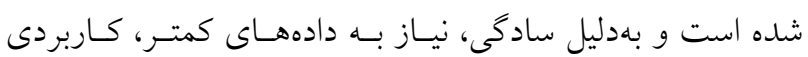


جدول ا. برخى ويزّكىهاى فيزيكى و شيميايى خاك مزرعه مورد آزمايش

\begin{tabular}{|c|c|c|c|c|c|c|c|c|c|c|c|}
\hline كربن & كل & فسفر & يتاسيم & $\mathrm{pH}$ & EC & يزّمردگى دائم & ظرفيت زراعى ربت & & جرم ن & بافت & عمق \\
\hline$(\%)$ & $(\%)$ & & & - & $\left(\mathrm{dS} \mathrm{m}^{-1}\right)$ & & & & & & $(\mathrm{cm})$ \\
\hline$\circ / \Delta \Delta$ & o/VY & $1 / 10$ & rAF & $N / \circ \mathrm{V}$ & $\circ \pi \Delta$ & $11 / 9$ & $r / / 4$ & $1 / 41$ & & سيلتى & ${ }^{0}-r_{0}$ \\
\hline $0 / 4 \Lambda$ & $\circ / V Y$ & $V / V$ & rqT & $N / \circ V$ & $0 M Y$ & $I T / Y$ & $r \mid / 4$ & $1 / \uparrow \wedge$ & & سيلتح & $r \circ-90$ \\
\hline
\end{tabular}

جدول r. نتايج تجزيه كيفيت آب آبيارى در مزارع آزمايشى

\begin{tabular}{|c|c|c|c|c|c|c|c|c|c|}
\hline سولفات & كلر & بى كربنات & كربنات & يتاسيم & سديم & منيزيم & كلسيم & $\mathrm{pH}$ & $\mathrm{EC}$ \\
\hline \multicolumn{8}{|c|}{$\left(\right.$ meq $\left.1^{-1}\right)$} & - & $\left(\mathrm{dS} \mathrm{m}^{-1}\right)$ \\
\hline$\circ / \Lambda$ & $0 / 4$ & $r / 9$ & - & - & $\circ / V$ & $r / 4$ & $r / 4$ & $V / V$ & $\circ / \mu V$ \\
\hline
\end{tabular}

مها روز رشد اول (استقرار بذر و رشد رويشى)، دوم (مر حله ميانى)

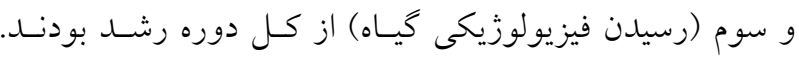

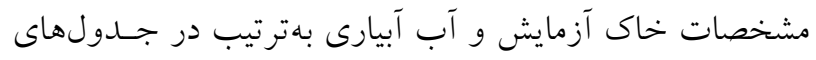
(1) و (Y) (Y) نشان داده شده است.

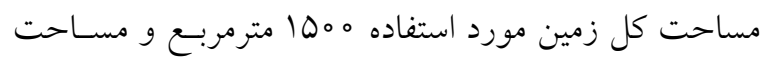

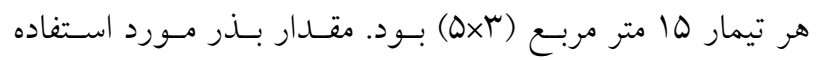

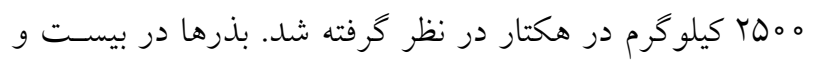
ششم ارديبهشت كاشته شدند و محصول نيز در اواخر مهر مـر مـاه

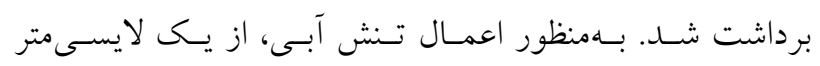
زهكشدار به عمق سه متر در مجاورت مزرعه مورد نظر استفاده

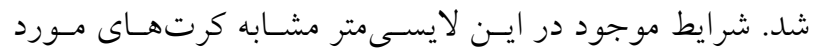

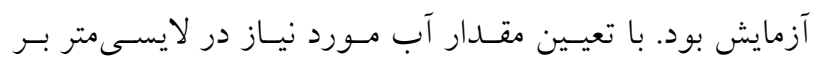

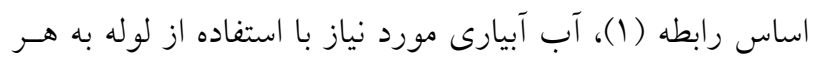

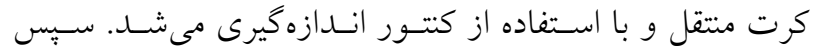
بلهورت ثقلى در سطح كرت بِخش مى شد. $\mathrm{ET}_{\mathrm{c}}=\mathrm{I}+\mathrm{R}-\mathrm{D} \pm\left(\mathrm{Sw}_{\mathrm{r}}-\mathrm{Sw}_{\uparrow}\right)$

در اين رابطه، ET

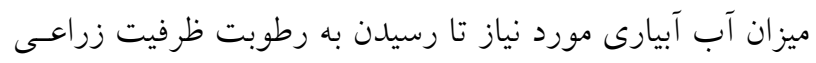

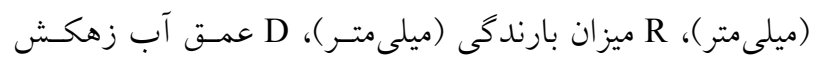

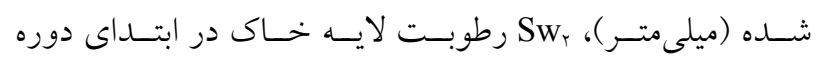

منابع در بالا بيانكر اين بود كه اعمـال تـنش آبسى در دورههـاى مختلف رشد نيز اثرات متفاوتى بـر عملكـرد سـيبزمينى دارد.

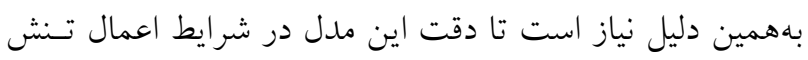

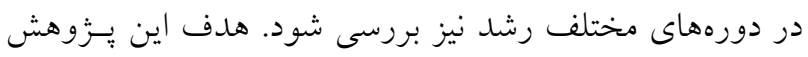
بررسى اثر تنش آبى در مقادير مختلف و در دورههاى متفـاوت رشد بر عملكرد و كارايى مصرف آب محصول است.

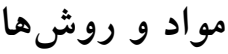

بمنظور ارزيابى مــل AquaCrop، دادههـاى برداشـت شــــ از مزرعه تحقيقاتى مركز تحقيقات كشاورزى واقـع در جهارتختسه

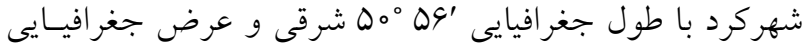

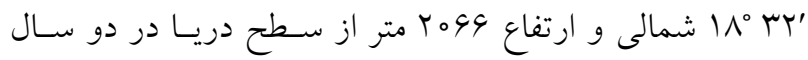

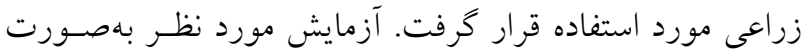

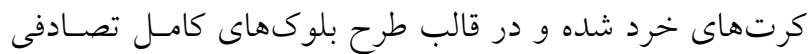

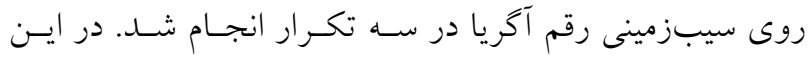
تحقيق از دو تيمار مقدار تنش آبى و زمان اعمال تسنش استفاده

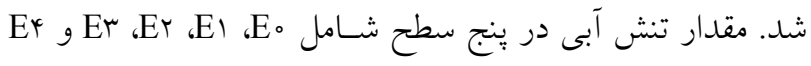

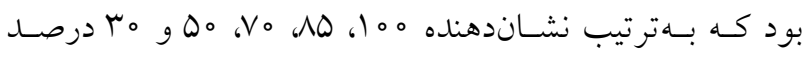

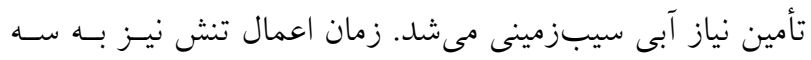

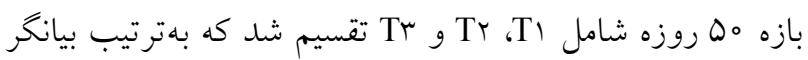


يوشش تاج (عكس روز) و t زمان (روز) اسـت. در ايسن مهدل،

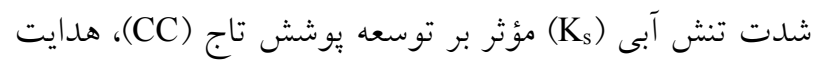

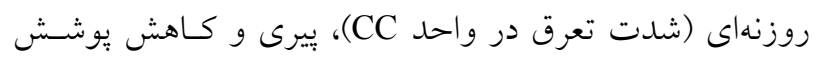

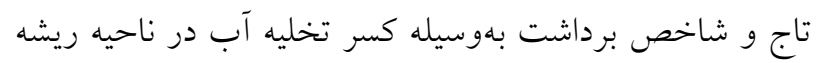

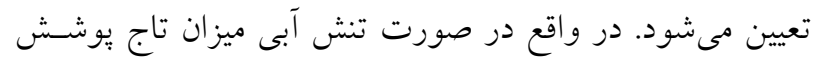

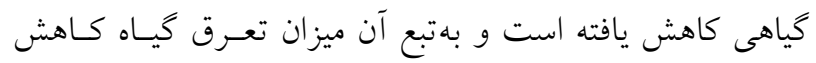

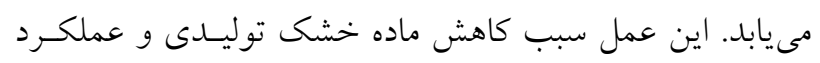

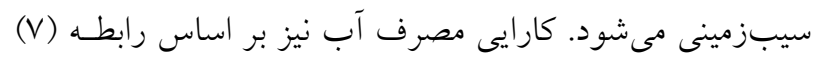
تعيين مى شود.

$$
\mathrm{WUE}=\frac{\mathrm{Y}}{\mathrm{W}}
$$

كـه در ايسن رابطـه، WUE كـارايى مصـرف آب (كيلـوكر بـر

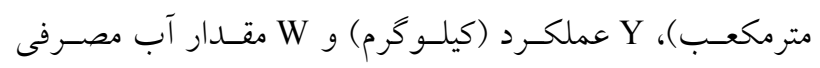

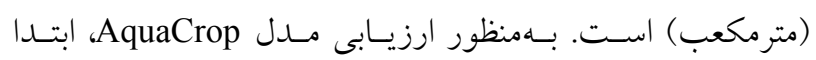
حساسيت اين مدل به يارامترهاى ورودى بــا استفاده از رابطـهـ ارائه شده توسط گيرت و رائس (V) سنجيده شد (رابطه N). $\mathrm{Sc}=\left|\frac{\mathrm{P}_{\mathrm{m}}-\mathrm{P}_{\mathrm{b}}}{\mathrm{P}_{\mathrm{b}}}\right| \times 100$

كه در اين رابطه، Sc ضريب حساسيت بــدون بعـد، Pm مقــدار برآورد شده بِارامتر مورد نظر بر اساس دادههاى وروودى تعـديل

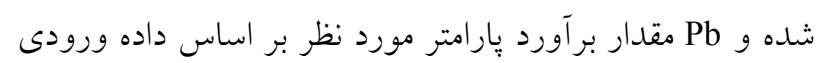

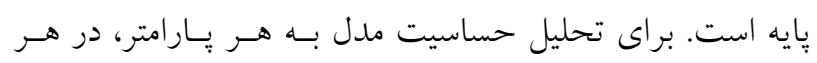

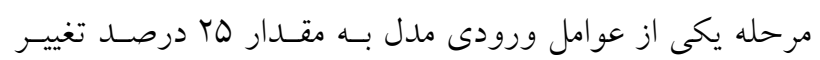

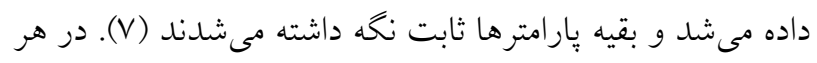
مرحلـه مقــدار ضــريب حساسـيت در ســه كـلاس، حساسـيت بــالا،

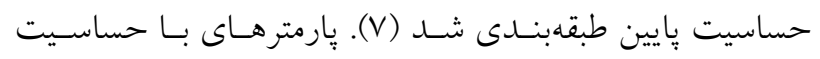

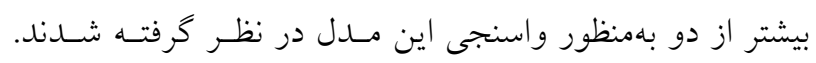

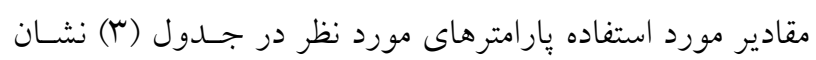

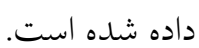

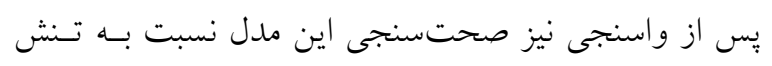

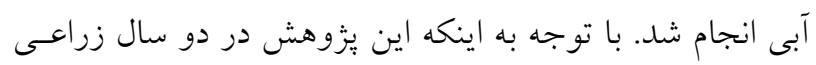

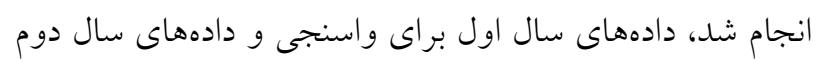

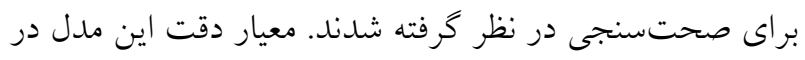

اندازهيرى (ميلىمتر) و Sw, رطوبت لابه خاك در انتهاى دوره

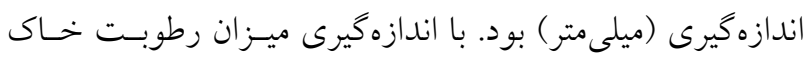

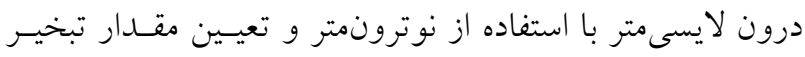

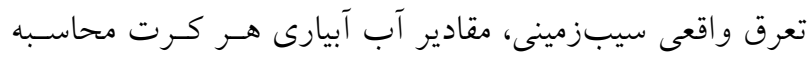

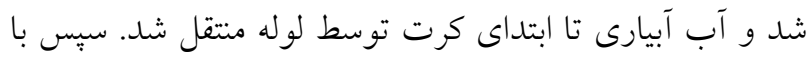

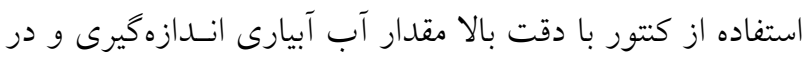
اختيار هر كرت قرار داده شد. يس از رسيدن محصول، برداشت فئست

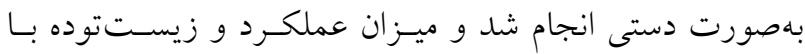
استفاده از ترازو سنجيده شدند.

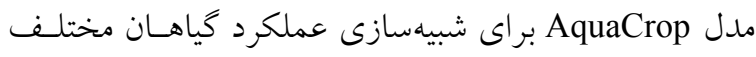
از رابطه (Y) استفاده مى كند (V).

$\left(\frac{Y_{x}-Y_{a}}{Y_{x}}\right)=K_{y}\left(\frac{E T_{x}-E T_{a}}{E T_{x}}\right)$

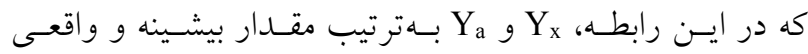
عملكرد محصول، ETx و ET به ترتيب مقدار بيشـينه و واقعى تبخير - تعرق كياه، و Ky ضريب نسبى ميـزان كـاهش محصدول

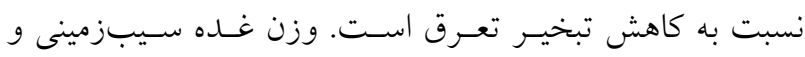

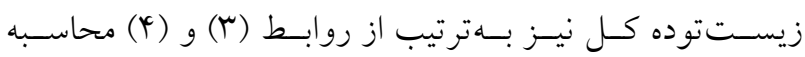

$\left.\mathrm{B}=\mathrm{WP} * \frac{\mathrm{Tr}_{\mathrm{i}}}{\mathrm{ET}_{0, \mathrm{i}}}\right]$

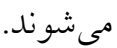
$\mathrm{Y}=\mathrm{B} \times \mathrm{HI}$

كه در اين روابط، Tr مقدار كـل تعـرق روزانـه در طـول فصـل

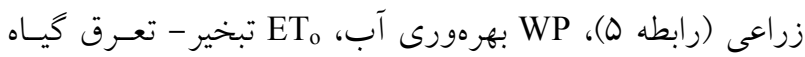

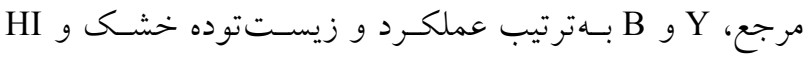
شاخص برداشت است.

$\mathrm{T}_{\mathrm{r}}=\mathrm{K}_{\mathrm{s}} \times \mathrm{CC} \times \mathrm{K}_{\mathrm{c}} \times \mathrm{ET}$

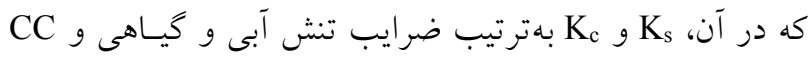

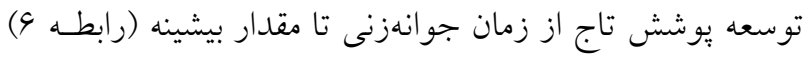

$\mathrm{CC}=\mathrm{CC} 。 \mathrm{e}^{\mathrm{CGC} \cdot \mathrm{t}}$

كـه در ايسن رابطـه، CC يوشـش تـاج در مر حلـه توسـعه كيـاه

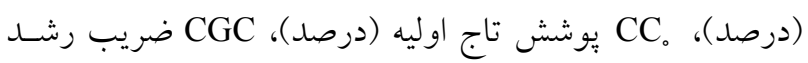


جدول r. مقادير عوامل گياهى مورد استفاده در مدل AquaCrop

\begin{tabular}{|c|c|c|c|}
\hline توضيح & واحد & مقدار & توضيح پيار امتر \\
\hline بيشفرض & درجه سانتى گر اد & $r$ & دماى بِايه \\
\hline ي بيشفرض & درجه سانتى گر اد & rq & 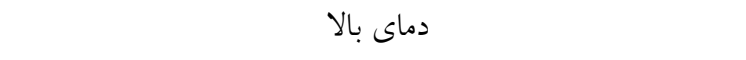 \\
\hline ي بيشفرض & درصد روز & $\Delta$ & ضريب رشد كانويى \\
\hline ي بيشفرض & 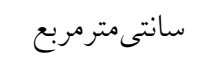 & 0 & يوشش گياهى هر نهال هنگام جوانهزنى \\
\hline ي بيشفرض & 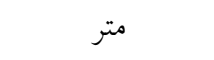 & $\circ / \mu$ & عمق مؤثر ريشه \\
\hline واسنجى & 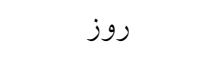 & 10 & مدت زمان كاشت تا جوانهزنى \\
\hline واسنجى & 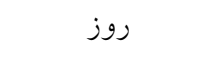 & ఎ० & مدت زمان كاشت تا بيشينه رشد كانويى \\
\hline 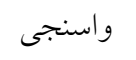 & 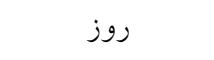 & $9 \circ$ & مدت زمان كاشت تا دوره يِيرى \\
\hline واسنجى & 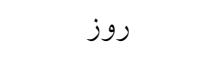 & 100 & مدت زمان كاشت تا برداشت محصول \\
\hline 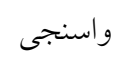 & 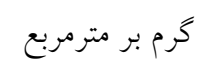 & ro & بهروورى آب نرمال شده \\
\hline واسنجى & درصد & 94 & بيشينه رشد كانويى \\
\hline واسنجى & - & $\circ / 4$ & حد بالا ضريب تخليه آب خاى براى توسعه گياه \\
\hline 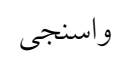 & - & $\circ / \wedge$ & حد يايين ضريب تخليه آب براى توسعه گياه \\
\hline واسنجى & مرصد روز & $10 / 0$ & ضريب رشد يوشش \\
\hline 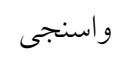 & درصد روز & $1 / 9$ & ضريب كاهش بوشش \\
\hline واسنجى & مرصد بر روز & $1 / 4$ & حداكثر ضريب گياهى براى تعرق \\
\hline 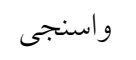 & - & $\circ / \mathrm{OV}$ & ضريب شكل براى ضريب تنش آبى بهمنظور بسته شدن روزنهها \\
\hline واسنجى & - & $\circ / V T$ & ضريب شكل براى ضريب تنش آبى براى مرحله يِيرى \\
\hline
\end{tabular}

$\mathrm{MBE}=\frac{\sum_{\mathrm{i}}^{\mathrm{n}}\left(\mathrm{P}_{\mathrm{i}}-\mathrm{O}_{\mathrm{i}}\right)}{\mathrm{n}}$

$E F=1-\frac{\sum_{i=1}^{n}\left(P_{i}-O_{i}\right)^{r}}{\sum_{i=1}^{n}\left(O_{i}-\bar{O}\right)^{r}}$

$d=1-\frac{\sum_{i=1}^{n}\left(P_{i}-O_{i}\right)^{r}}{\sum_{i=1}^{n}\left(\left|P_{i}\right|+\left|O_{i}\right|\right)^{r}}$

$\mathrm{R}^{r}=\frac{\left(\sum\left(\mathrm{P}_{\mathrm{i}}-\overline{\mathrm{P}}\right)\left(\mathrm{O}_{\mathrm{i}}-\overline{\mathrm{O}}\right)\right)^{r}}{\sum\left(\mathrm{P}_{\mathrm{i}}-\overline{\mathrm{P}}\right)^{r} \sum\left(\mathrm{O}_{\mathrm{i}}-\overline{\mathrm{O}}\right)^{r}}$
هر دو مرحله واسنجى و صحتسنجى با استفاده از آمارههـاى

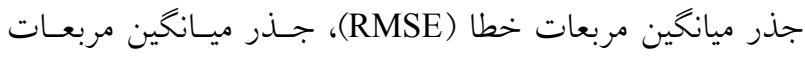

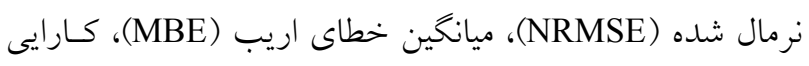

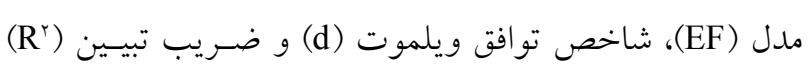

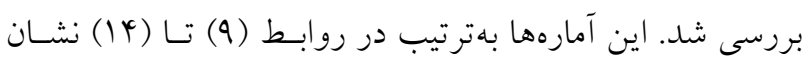
داده شدهاند.

RMSE $=\sqrt{\frac{\sum_{\mathrm{i}=1}^{\mathrm{n}}\left(\mathrm{P}_{\mathrm{i}}-\mathrm{O}_{\mathrm{i}}\right)^{r}}{\mathrm{n}}}$

NRMSE $=\frac{\sqrt{\frac{\sum_{i=1}^{n}\left(P_{i}-O_{i}\right)^{r}}{n}}}{\overline{\mathrm{O}_{i}}}$ 


\section{جدول أ. ضريب حساسيت برخى عوامل ورودى مدل رشد گياهى AquaCrop براى شبيهسازى عملكرد سيبزمينى}

\begin{tabular}{|c|c|c|c|}
\hline درجه حساسيت & مقدارSc در حالت QY- درصد & مقدارSc در حالت QT++ درصد & 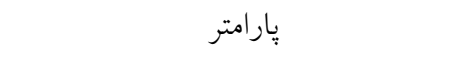 \\
\hline زياد- زياد & $10 / 4$ & $10 / V$ & رطوبت در ظرفيت زراعى \\
\hline متوسط - متوسط & $10 / 0$ & $V / \omega$ & رطوبت در نقطه يُمردگى \\
\hline متوسط - كم & $1 / 4$ & $r / 9$ & رطوبت در حالت اشباع \\
\hline كم - متوسط & $r / 9$ & M & ضريب گياهى براى تعرق \\
\hline متوسط - كم & $1 / 4$ & $\Gamma / 9$ & عمق مؤثر ريشه \\
\hline متوسط - متوسط & $9 / 4$ & $9 / 9$ & مدت زمان كاشت تا جوانهزنى \\
\hline متوسط - متوسط & $10 / 9$ & $\Lambda / 1$ & مدت زمان كاشت تا بيشينه رشد كانويى \\
\hline ز مياد- متوسط & $T / I$ & $r \circ / \Delta$ & مدت زمان كاشت تا برداشت محصول \\
\hline زياد- متوسط & $\varphi / 0$ & $Y Y / l$ & مدت زمان كاشت تا دوره بيرى \\
\hline
\end{tabular}

جدول (Y) نشان داده شده است. همانطور كـه در ايسن جـدول

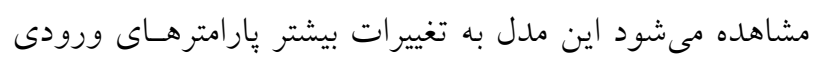

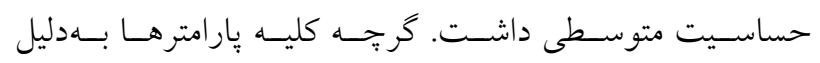
محدوديت نغارش در اين جدول نشان داده نشد. ليكن مشاهده

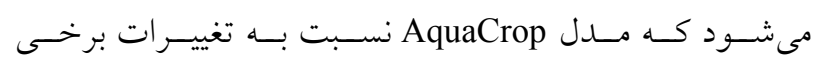

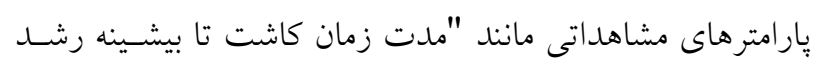

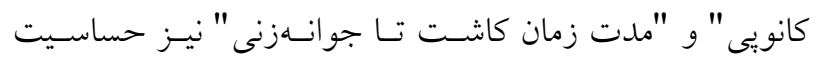

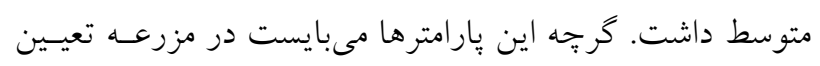

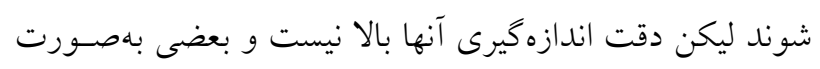

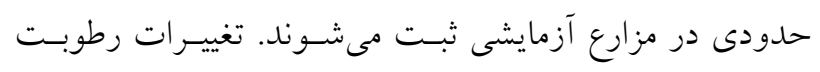

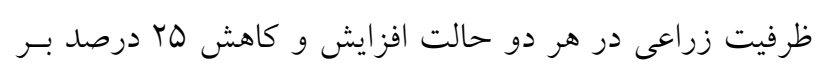

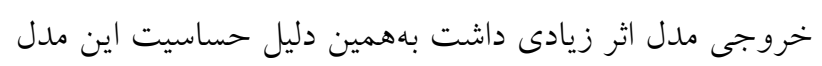

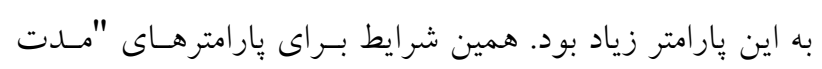

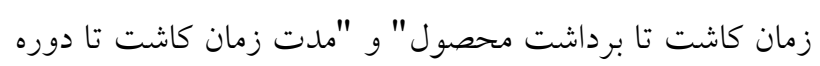

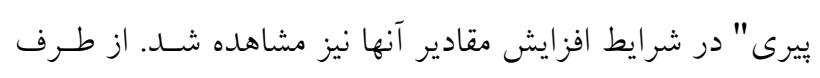

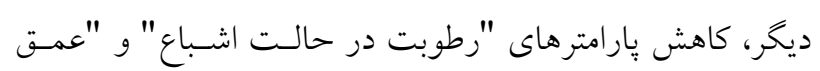

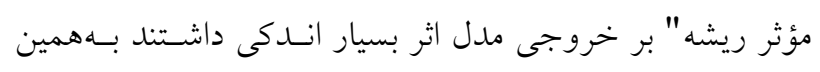
دليل حساسيت اين مدل نسبت به كاهش مقادير ايـن بارامترهـا

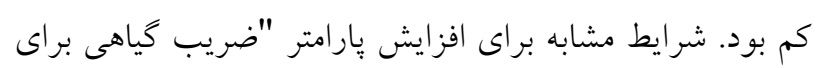

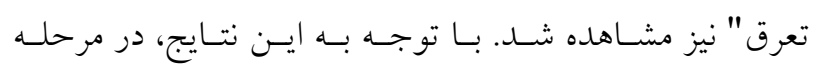

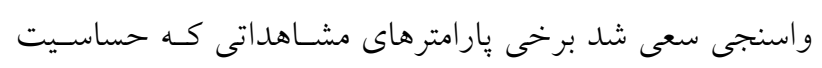

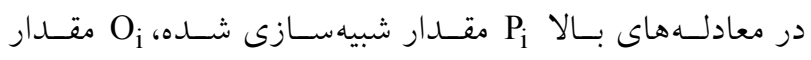
انــازه كيرى شـده،

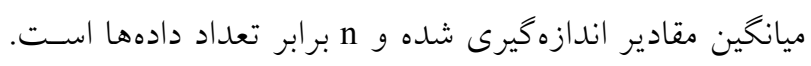

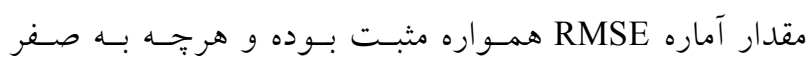

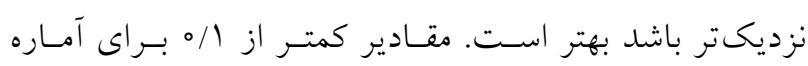

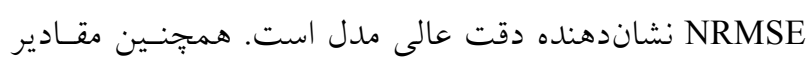

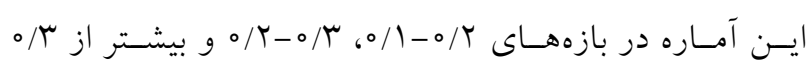

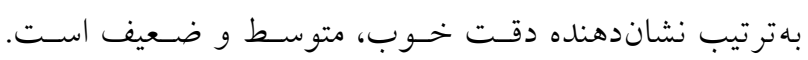

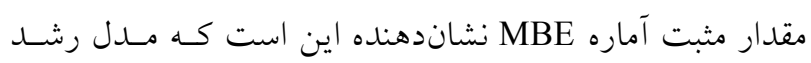

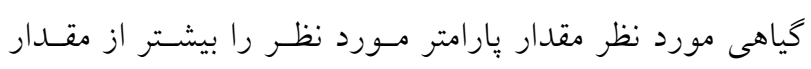

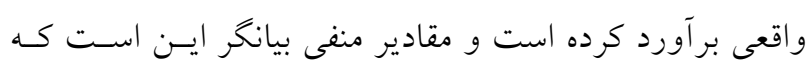

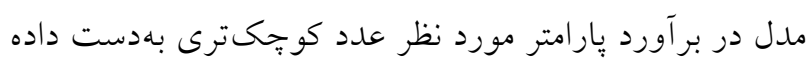

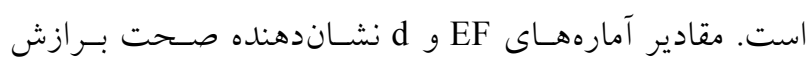

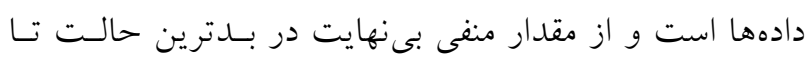

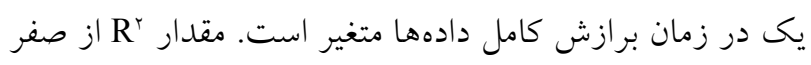

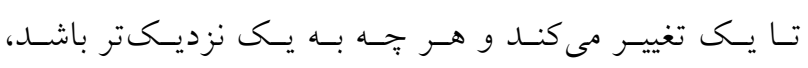
نشاندهنده برازش بهتر دادهها است.

بحث و نتايج تحليل حساسيت نتايج بهدست آمـده از تحليـل حساسـيت مــل AquaCrop در 


\begin{tabular}{|c|c|c|c|c|c|c|}
\hline $\mathrm{d}$ & $\mathrm{EF}$ & MBE & NRMSE & RMSE & 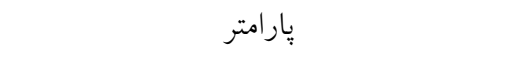 & مرحله از شبيهسازى \\
\hline.$/ 99$ & $\circ / 99$ & $-\circ / T \Delta$ &.$/ 9$ & $r / l$ & عملكرد (تن بر هكتار) & \multirow{2}{*}{ واسنجى } \\
\hline.$/ 99$ & $\circ / 99$ & O/YT & $\circ / T V$ & $0 / 09$ & كارايى مصرف آب (كيلو گرم بر مترمكعب) & \\
\hline$\circ / 99$ & $\circ / 90$ & $-\circ / N$ & $\circ / \circ \Delta$ & $1 / 0$ & عملكرد (تن بر هكتار) & \multirow{2}{*}{ صحتسنجى } \\
\hline$\circ / 9 V$ & $\circ / 91$ & $-0 / 91$ & $\circ / T Q$ & $1 / \circ \Lambda$ & كارايى مصرف آب (كيلو گرم بر مترمكعب) & \\
\hline
\end{tabular}

\section{صحت سنجى مدل AquaCrop} نتايج مشابه براى مرحله صحتسنجى نيز نشان داد كـه مقـادير بهدست آمده براى عملكرد قابل قبول است (جدول ه). مقـادير

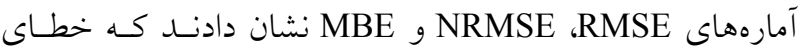
شبيهسازى اين بِارامتر در اين مرحله قابل قبول است. خطاى بـه

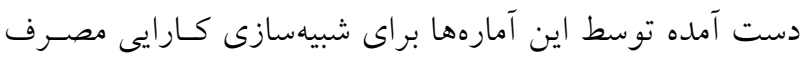

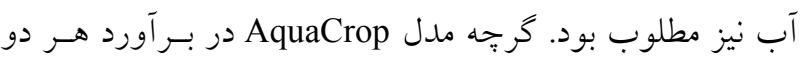
بارامتر عملكرد و كارايى مصرف آب در مرحلـه صحتسـنجى دجار خطاى كمبرآوردى شد. آمارههاى EF و d نيز براى هر دو بارامتر نشان داد كه كارايى مــل AquaCrop بــراى شبيهسـازى أنها مناسب است. همجنين مقايسه نتايج در سطوح و زمانهـاى مختلف تنش نشان داد كه مــل AquaCrop در تنشهـاى آبسى شديدتر دقت كمترى داشت (جدول 9). دقت اين مدل در زمان نيز نسبت به دو زمان ديخر كاهش يافـت. ضـريب تبيـين (Tr) بين مقادير شبيهسازى و مشاهداتى عملكـــد و كـارايى مصـرف آب در شكل (1) نشان داده شده است. همانطور كـه مشـاهده مىشود اين مقادير براى هر دو پيارامتر عملكرد و كارايى مصرف آب قابل قبول است. يزوهشخران ديخر از جمله ماسانخانيس و

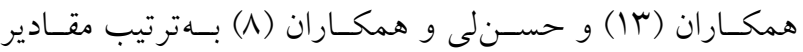

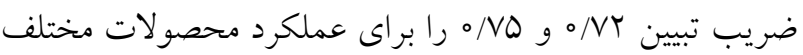

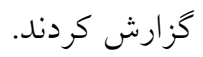

عملكرد سيبزمينى با توجه بـه نتـايج بهدسـت آمـده از مرحلـه واسـنجى، مقـادير شبيهسازى عملكرد هـر تيمـار در مقابـل مقــادير مشـاهداتى آن
مدل نسبت به تغييرات آنها متوسـط و زيـاد اسـت نيـز در نظـر كرفته شود. بهعنوان مثال "ملت زمان كاشـت تـا بيشـينه رشـــ كانويى" و "مدت زمان كاشت تا جوانهزنى" كه مقادير Sc براى آنها بيشتر از 4/ بودد؛ مورد واسنجى قرار گرفتند و مقادير آنهـا در جدول (r) آورده شد. همانطور كه مشاهده مىشود در ايسن جدول برخى يِارامترهاى ورودى مدل نشان داده شدهاند.

\section{واسنجى مدل AquaCrop}

نتايج واسنجى مدل با استفاده از اين يارامترهـا در جــدول (ه) نشان داده شده است. همانطور كه مشـاهده مىشـود؛ مقــادير RMSE براى عملكرد قابل قبول است. مقـدار بهدسـت آمــده براى NRMSE نيز نشان داد كه دقت اين مدل در اين مرحلـه عالى است. نتايج آماره MBE براى اين مدل نشان داد كه ايسن مدل دجار خطاى كمبــرآوردى در شبيهسـازى عملكـــد شـده است ولى با اين وجود كارايى اين مدل با توجه بـهـ دو آمـاره

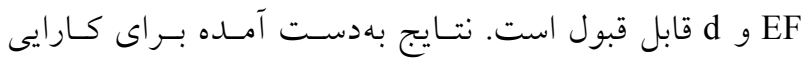
مصرف آب در مرحله واسنجى نيز نشان داد كه مقادير بهدست آمده براى اين پيارامتر با توجسه بـهـ دو آمـاره RMSE و MBE قابل قبول است. گرجهه مــل AquaCrop در شبيهسـازى ايسن پارامتر دجار خطاى بيش برآوردى شد. اين نتايج با مشاهدات كاترجى و همكاران (11) و حسنلى و همكاران (1) مطابقـت داشت. مقدار آماره NRMSE براى اين بـارامتر نشـان داد كـهـ دقـت ايـن مــدل در شبيهسـازى ايسن :ــارامتر خــوب اسـت. آمارههاى EF و d نيز بيانخر قابل قبول بودن كارايى اين مـدل بودند. 
جدول 9. مقادير شاخصهاى آمارى براى شبيهسازى عملكرد و كارايى مصرف آب سيبزمينى در تنشهاى مختلف

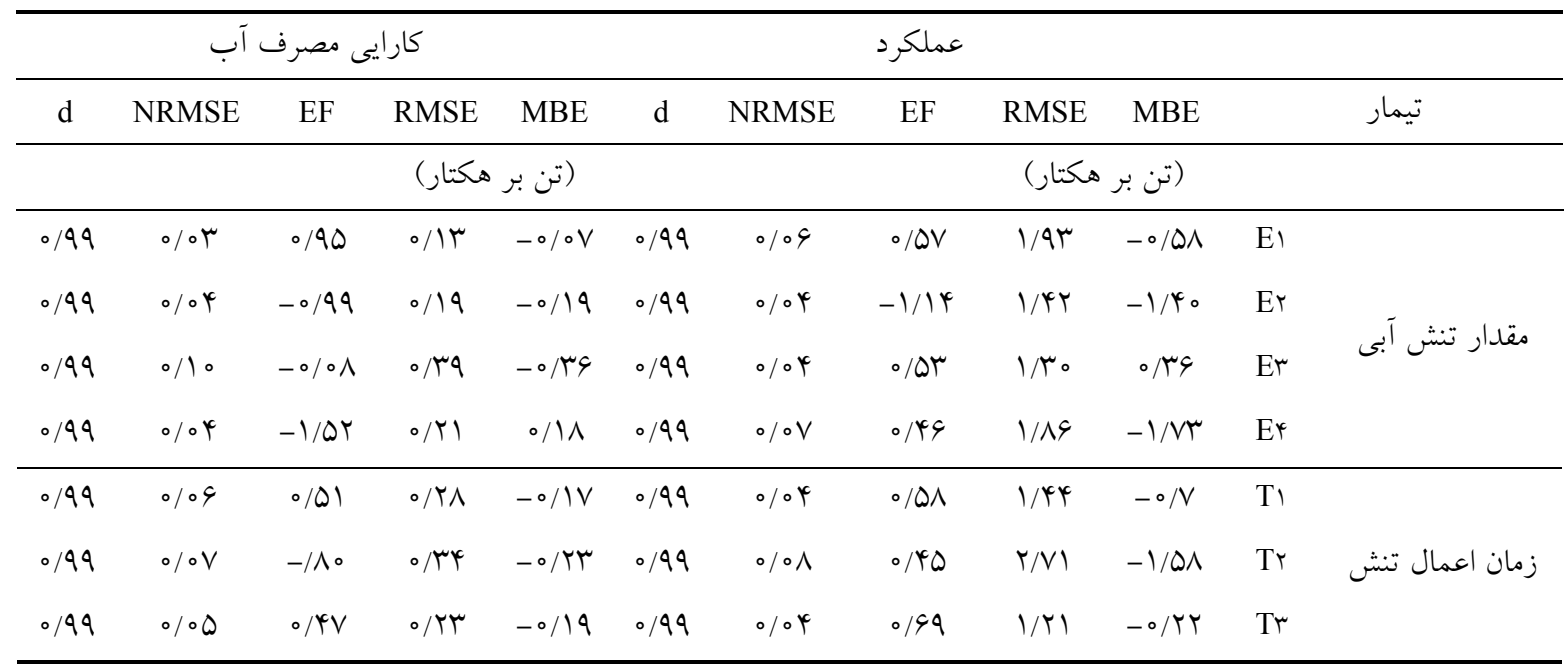

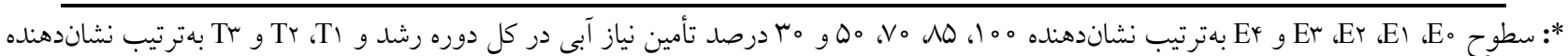
اعمال تنش در •ه روز رشد اول (استقرار بذر و رشد رويشى)، •ه روز دوم رشد (مرحله ميانى) و •ه روز سوم رشد (رسيدن فيزيولوزيكى كياه) است.
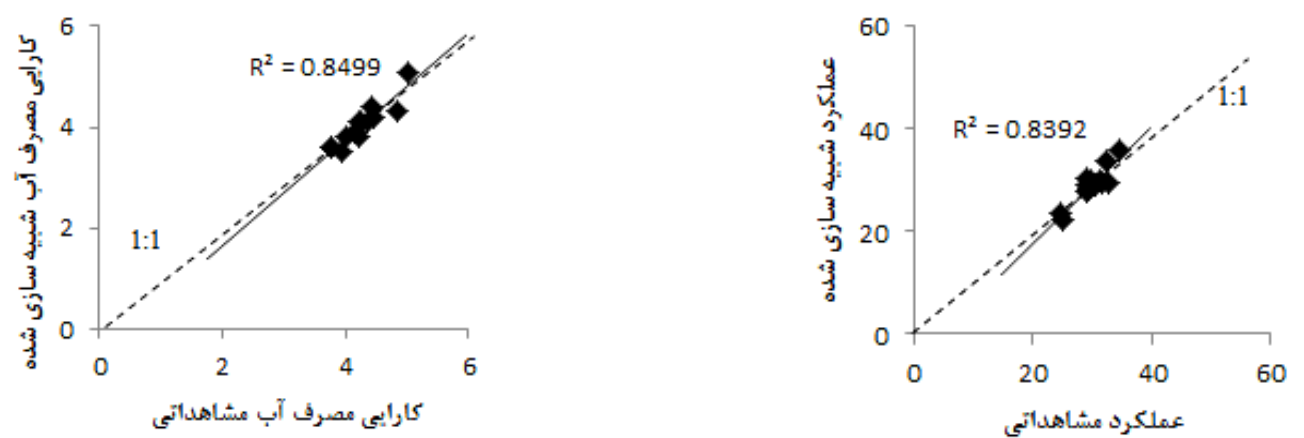

شكل 1. همبستخى مقادير مشاهداتى و شبيهسازى شده عملكرد (بر حسب تن بر هكتار ) و كارايى مصرف آب (كيلوكرم بر مترمكعب) سيبزمينى (اين شكل براى كليه حالات تنش رسم شده است)

شد كه خطاى كمترى در شبيهسـازى مشـاهلده شـود. از طـرف

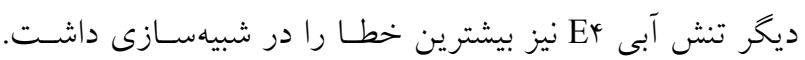
كر جــه تحقيقـات مختلـف از جملـه هنـع و همكــاران (9) و هسيائو و همكــاران (0 () نشـان داده اسـت كـه خطـاى مــل AquaCrop اين مطالعه روند افزايشى مشاهده نشد. كمترين ميـزان خطـا در تنش آبى Er و يس از آن در تنش آبى El مشاهده شد. بـرهمكـــ مقادير تنش در مراحل مختلف رشـــ نيـز نشـان داد كـه كمتـرين و بيشترين اختلاف بين مقادير مشاهداتى و شبيهسازى بـهترتيب برابـر

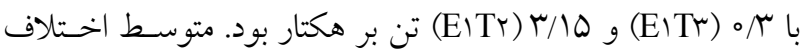

مورد مقايسه قرار گرفت (شـكل Y). همهنجـين مقـادير ميـانكين عملكرد و كارايى مصرف آب به تقكيك مقــار و زمـان اعمـال تنش نيز در جدول (V) نشان داده شده است. متوسـط اخـتلاف عملكرد شبيهسـازى و مشـاهداتى تيمارهـاى El، Er، Er و Er Er

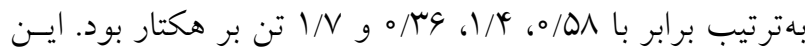

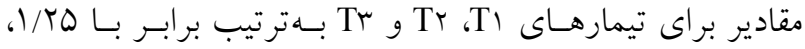

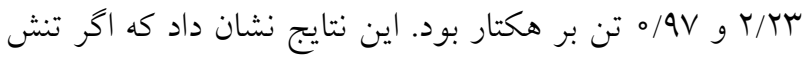
آبى در مرحله دوم رشد به اين كياه وارد شود؛ مدل AquaCrop دقت بايينترى نسـبت بـه دورههــاى اول و سـوم رشـــ بـراى شبيهسازى عملكرد آن دارد. تنش وارده در مرحله سـوم باعـث 


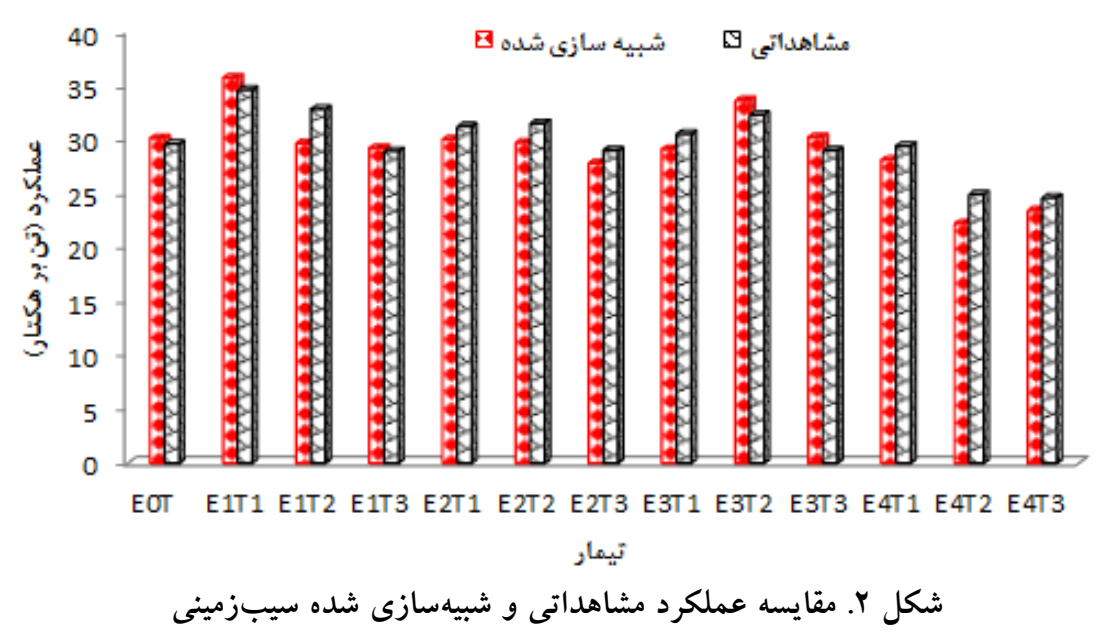

\begin{tabular}{|c|c|c|c|c|c|}
\hline \multicolumn{2}{|c|}{ كارايى مصرف آب (كيلو گرم بر مترمكعب) } & \multicolumn{2}{|c|}{ عملكرد (تن بر هكتار) } & & \multirow{2}{*}{ تيمار } \\
\hline AquaCrop & مشاهداتى & AquaCrop & مشاهداتى & & \\
\hline$r / 0$ & $r / 9$ & $r \circ / 1$ & $r q / 9$ & E。 & \multirow{5}{*}{ مقدار تنش آبى } \\
\hline$r / r$ & $r / 4$ & $M 1 / \Delta$ & $r Y / l$ & E) & \\
\hline$\psi /$ & $1 / 4$ & $r 9 / 1$ & $r \circ / \phi$ & Er & \\
\hline$r / 9$ & $r / r$ & $r \circ / 9$ & $r_{0 / 9}$ & Er & \\
\hline$\psi / 1$ & $r / 4$ & $\Gamma \Psi / Q$ & $r q / r$ & $\mathrm{Er}^{r}$ & \\
\hline$r / r$ & $r / \varphi$ & $r \circ / V$ & $r \mid / 4$ & $\mathrm{~T} 1$ & \multirow{3}{*}{ زمان اعمال } \\
\hline$r / r$ & $r / \Delta$ & rN/A & $\mu \circ / \mu$ & $\operatorname{Tr}$ & \\
\hline$r / \Lambda$ & $r / 9$ & $T V / Q$ & $r V / \Lambda$ & $\mathrm{Tr}$ & \\
\hline
\end{tabular}

در بيشتر تيمارهـا مقــدار كـارايى مصـرف آب كمتـر از مقــادير

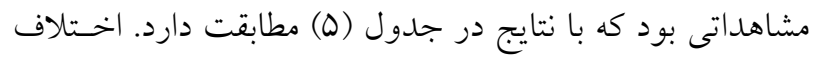

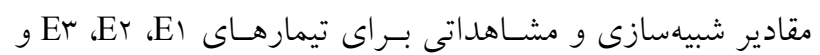

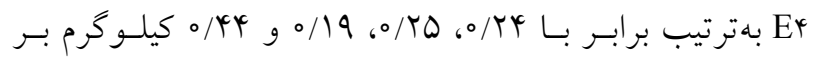
مترمكعب بود. روند نسبتاً افزايشى در خطاى مـدل AquaCrop در مقادير بسيار كم و بسيار زياد تنش آبى مشاهده مى شودد.

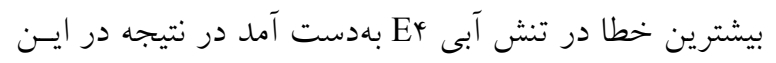

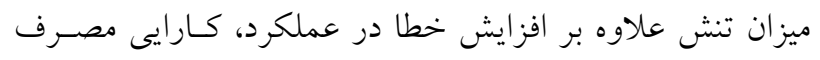

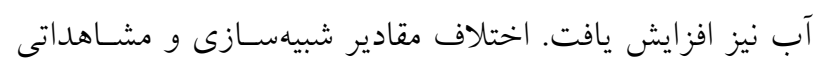

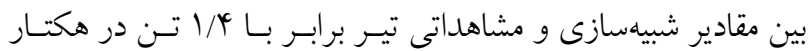

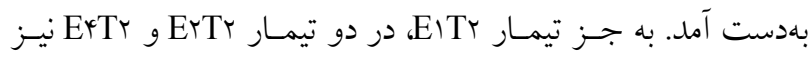
اختلاف مقادير مشاهداتى و شبيهسازى بيشـتر از بع/1 تـن در هكتـار

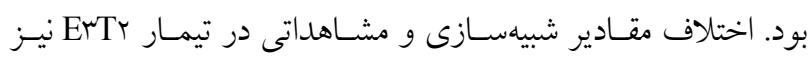
نزديك به اين مقدار و تنها هشت درصد از آن كمتر بود.

$$
\text { كارايى مصرف آب }
$$

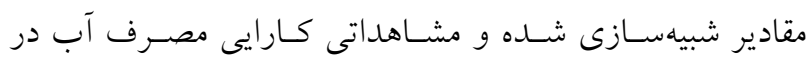

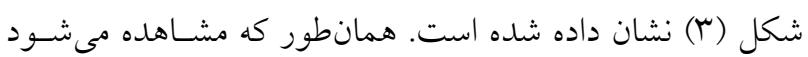




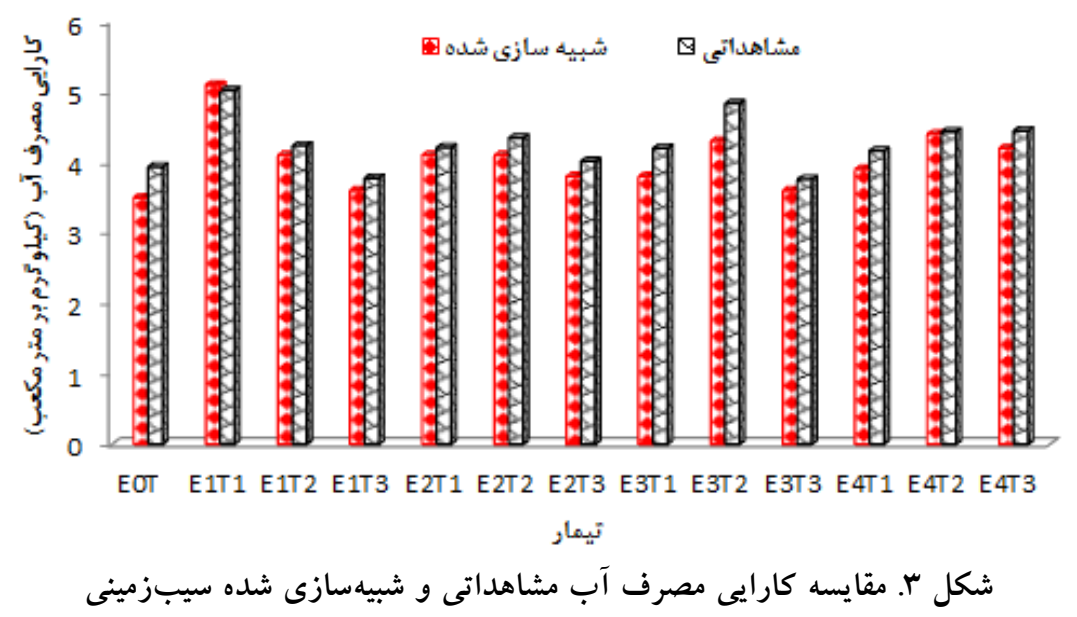

نسبت به دو مرحله ديكر رشد شد. نتـايج بهدسـت آمــه بـراى

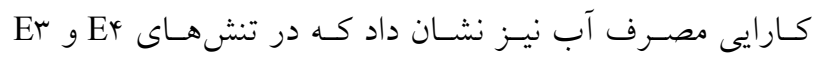
بهترتيب بيشترين و كمترين اختلاف بين مقادير شبيهسازى شده

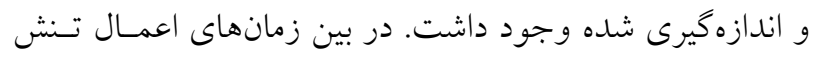

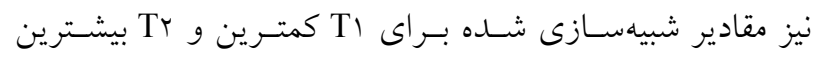
اختلاف را با مقادير اندازهيرى شده داشتند. جمعبنـدى نتسايج

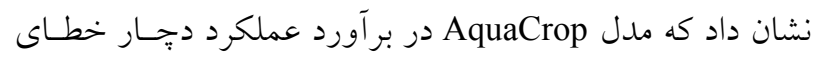

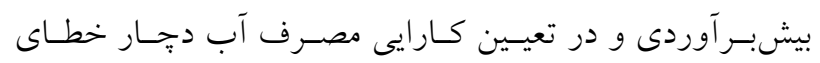

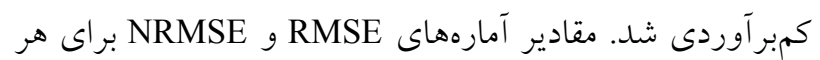
دو يارامتر عملكرد و كارايى مصرف آب نشان داد كه اين مــدل داراى خطاى قابل قبول در شبيهسازى است. بنابراين مىتوان از

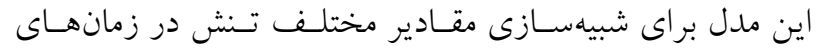
كوناكون در طول دوره رشد سيبزمينى استفاده كرد.

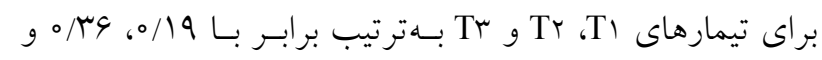

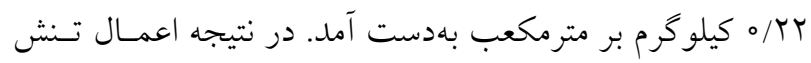

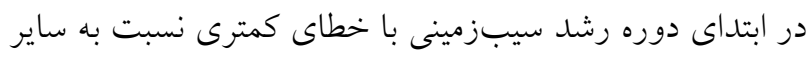

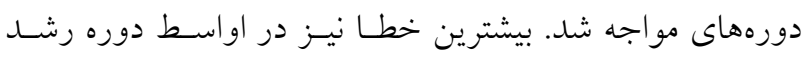

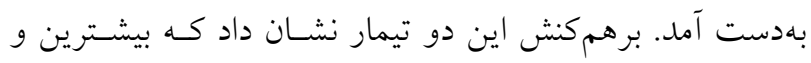

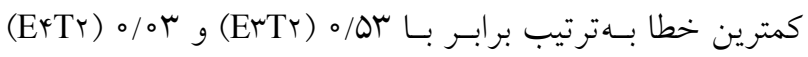

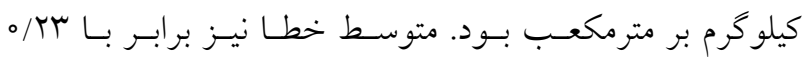
كيلو گرم بر مترمكعب بهدست برمت آمد.

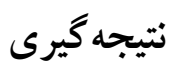

نتايج بهدست آمده در اين مطالعه نشان داد كمترين ميـزان خطـا

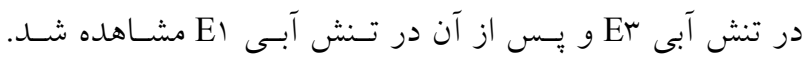

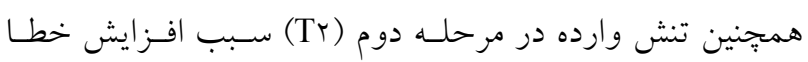

1. Afshar, A. and A. Neshat. 2013. Evaluation of AquaCrop computer model in the potato under irrigation management of continuity plan of Jiroft region, Kerman, Iran. International Journal of Advanced Biological and Biomedical Research 1(12): 1669-1678.

2. Doorenbos, J. and A. H. Kassam. 1979. Yield response to water. FAO Irrigation and Drainage, Paper 33, Rome.

3. Ebrahimipak, N. A. 2014. Determination of the potato yield response factor $(\mathrm{Ky})$ to deficit irrigation in different growth stages in shahrekord. Journal of Irrigation and Water Engineering 4(15): 39-50.

4. Ebrahimipak, N. A., A. Egdernejad and D. Khodadadi Dehkordi. 2018. Evaluation of AquaCrop model to simulate corn yield under water deficit and superabsorbent application. Journal of Irrigation and Water Engineering 8(3): 166-184. (In Farsi).

5. Eskandari, A., H. R. Khazaie, M. A. Nezami and M. Kafi. 2011. Study the effects of irrigation regimes on yield and some qualitative characteristics of three cultivars of potato (Solanum tuberosum L.). Journal of Water and Soil 25(2): 240-247. (In Farsi). 
6. Garcia-Vila, M. and E. Fereres. 2012. Combining the simulation crop model AquaCrop with an economic model for the optimization of irrigation management at farm level. European Jornal of Agronomy 36(1): 21-31.

7. Geerts, S. and D. Raes. 2009. Defecit irrigation as on-farm strategy to maximize crop water productivity in dry areas. Agricultural Water Management 96: 1275-1284.

8. Hassanli, M., P. Afrasiabi and H. Ebrahimian. 2015. Evaluation of AquaCrop vs Saltmed models to estimate crop yield and soil salinity. Iranian Journal of Soil and Water 46(3): 487-498. (In Farsi).

9. Heng, L. K., T. C. Hsiao, S. Evett, T. Howell and P. Steduto. 2009. Validating the FAO AquaCrop model for irrigated and water deficient field maize. Agronomy Journal 101(3): 488-498.

10. Hsiao, T. C., L. Heng, P. Steduto, B. Rojas-Lara, D. Raes and E. Fereres. 2009. AquaCrop-The FAO crop model to simulate yield response to water: III. Parameterization and testing for maize. Agronomy Journal 101(3): 448-459.

11. Katerji, N., P. Campi and M. Mastrorilli. 2013. Productivity, evapotranspiration, and water use efficiency of corn and tomato crops simulated by AquaCrop under contrasting water stress conditions in the Mediterranean region. Agricultural Water Management 130: 14-26.

12. Khoshravesh, M., A. Ghadamifiroozabadi, P. Shirazi and M. Najafimood. 2015. Cotton response simulation to dry and salinity stress by using of AquaCrop model. Journal of Irrigation and Water Engineering 6(1): 166-179. (In Farsi)

13. Masanganise, J., K. Basira, B. Chipindu, E. Mashonjowa and T. Mhizha. 2013. Testing the utility of a crop growth simulation model in predicting maize yield in a changing climate in Zimbabwe. International Journal of Agricultural and Food Science 3(4): 157-163.

14. Montaya, F., D. Camargo, J. F. Ortega, J. I. Corcoles and A. Dominguez. 2016. Evaluation of AquaCrop model for a potato crop under different irrigation conditions Agricultural Water Management 164(2): 267-280.

15. Shock, C. C. 2004. Efficient Irrigation Scheduling. Malheur Experiment Station, Oregon State University, Oregon, USA.

16. Yuan, B. Z., S. Nishiyama and Y. Kang. 2003. Effects of different irrigation regimes on the growth and yield of drip- irrigated potato. Agricultural Water Management 63: 153-167. 


\title{
Evaluation of AquaCrop Model for the Simulation of Potato Yield and Water Use Efficiency under Different Water Stress Values in Different Growth Cycles
}

\author{
M. A. Ansari ${ }^{1}$, A. Egdernezhad ${ }^{*}$ and N. A. Ebrahimipak ${ }^{2}$
}

(Received: March 12-2019 ; Accepted: June 25-2019)

\begin{abstract}
This study was conducted to evaluate AquaCrop for the simulation of potato yield and water use efficiency (WUE) under different water stress values at five levels (E0, E1, E2, E3 and E4, indicating 100, 85, 70, 50 and 30 percent of crop water needed, respectively) in three times during growth cycles (T1, T2, and T3, indicating 50, 100, and 150 days after sowing, respectively). The results showed that AquaCrop had overestimated and underestimated error for the simulation of yield and WUE, respectively. Based on RMSE and NRMSE values, the errors for yield and WUE were acceptable. The maximum and minimum error were also 0.3 (E1T3) and 3.15 (E1T2), respectively. The results obtained for WUE showed that the maximum and minimum were 0.53 (E3T2) and 0.03 (E4T2), respectively. The average differences between simulated and observed results (ADSO) of WUE for E1, E2, E3 and E4 were 0.24, 0.25, 0.19, and 0.44 ton.ha $^{-1}$, respectively; the ADSO of yield for T1, T2, and T3 was $0.19,0.36$, and 0.22 ton.ha $^{-1}$, respectively. Therefore, AquaCrop showed a high error for WUE when water stress was increased and crop was in its initial crop growth.
\end{abstract}

Keywords: AquaCrop model, Potato yield, Crop modeling, Water stress

1. Department of Water Sciences and Engineering, Ahvaz Branch, Islamic Azad University, Ahvaz, Iran.

2. Department of Irrigation and Soil Physics, Soil and Water Research Institute, Agricultural Research, Education and Extension Organization (AREEO), Karaj, Iran.

*: Corresponding author: a_eigder@ymail.com 